\title{
Změna hodnotových preferencí české společnosti a tvưrcủ zahraniční politiky jako jeden z předpokladů transformace české zahraniční politiky ${ }^{1}$
}

\author{
Change of Value Preferences of Czech Society and of Foreign \\ Policy Makers as One of Prerequisites of Transformation of Czech \\ Foreign Policy Character
}

\author{
Šárka Waisová
}

\begin{abstract}
Political emancipation of Czechoslovakia in 1989 created the conditions for fundamental political, societal and economical restructuring. The democratic transition opened the space for the change of the character of Czech foreign policy. One of the resources of the change has been the transformation of value preferences of Czech society and foreign policy makers. The transformation of value preferences which has taken place in Czech Republic since 1989 is similar to the "silent revolution" that rose in West European societies in 1970s. Analyzing the Czech foreign policy I come out from the ideas, that 1. the identity of states is formulated be the political representation on the bases of the facts (values), which the society declares for and find itself in, and 2. that the values drive and determine activities and attitudes. The transformation of value preference of Czech society and Czech foreign policy makers will logically invoke the change of the character of Czech foreign policy.
\end{abstract}

KEY WORDS character of Czech foreign policy, materialism, postmaterialism, social change,

Politická emancipace Československa po roce 1989 otevřela prostor pro zásadní restrukturalizaci politických, společenských a ekonomických poměrů. Transformace Československa společně s novým geopolitickým diskursem nastoleným po skončení studené války a se změnou charakteru mezinárodního systému vytvořily podmínky pro (re)konstrukci českého národního zájmu a povahy české zahraniční politiky. Zdrojem této (re)konstrukce se staly

Sociální studia. Fakulta sociálních studií Masarykovy univerzity, 4/2010. S. 145-157. ISSN 1214-813X.

1 Tento text vznikl v rámci projektu Národní program výzkumu II, č. 2D06010 „Evropská integrace a zájmy ČR“. Sběr dat použitých v analýze byl financován projektem GAČR č. 403/08/0999 „Hodnotové proměny v ČR 1991-2008 v evropském kontextu“. Za pomoc při zpracování dat EVS děkuji Martinu Kreidlovi, za pomoc při zpracování dat týkajících se vzdělání členů Parlamentu ČR děkuji Lindě Piknerové. Za podnětné komentáře děkuji dvěma anonymním recenzentům. 
zejména vliv českého disentu na podobu zahraniční politiky, již zmíněná domácí politická, společenská a ekonomická transformace, změna hodnotových preferencí, idejí a identity společnosti, zejména tvůrců zahraniční politiky, a změna referenční skupiny České republiky či jinými slovy společenství, do něhož je socializována. Tento text se zaměří na analýzu jednoho ze zdrojů (re)konstrukce povahy české zahraniční politiky, a to na hodnotové preference, ideje a identitu společnosti a tvůrců zahraniční politiky. Takový prŕstup nám samozřejmě poskytne jen dílčí odpověd’ na otázku, jak se mění český národní zájem a povaha české zahraniční politiky a jaké jsou zdroje této změny, nicméně tento text nechce $\mathrm{a}-\mathrm{s}$ ohledem na svůj rozsah - ani nemůže nabídnout více (ostatním třem zdrojům se samostatně věnuji v jiných textech - např́ílad Waisová a Piknerová 2010).

Předkládaný text je vystavěn na dvou předpokladech: 1. Hodnotové preference, ideje a identita společnosti a tvůrců zahraniční politiky mají vliv na povahu zahraniční politiky; a 2. česká společnost prošla po roce 1989 zásadní proměnou, která zasáhla její hodnotové preference (posun od materialismu $\mathrm{k}$ postmaterialismu), ideje (posun od komunismu k západní kultuře) a identity (návrat do Evropy, respektive do rodiny evropských národů, z níž byla po roce 1948 násilně vytržena). Odvozeno od těchto předpokladů, pokud došlo ke změně hodnotových preferencí, idejí a identity české společnosti a tvůrců zahraniční politiky, lze očekávat, že dojde či dochází ke změně povahy zahraniční politiky. Úvaha o vlivu hodnotových preferencí, idejí a identity společnosti a tvůrců zahraniční politiky na povahu zahraniční politiky vychází z toho, že:

1. Hodnoty jsou referenčním metodologickým rámcem, $v$ jehož mezích lze pochopit a vysvětlit ostatní společenské jevy. Hodnoty představují kognitivní reprezentaci potřeb, které se transformovaly tak, že do sebe včleňují také institucionální cíle a požadavky. Působí jako intervenující proměnné, které vedou člověka $\mathrm{k}$ činnosti, a ipso facto změna hodnot vyvolá změnu činnosti. Hodnoty „ک̌́́dí a determinují jednání, postoje k předmětům a situacím, ideologii, prezentaci sebe k druhým, hodnocení, posuzování, ospravedlňování, srovnávání sebe s ostatními a pokouší se ovlivňovat druhé“ (Rokeach podle Suchánková 1990: 531). Na supraindividuální rovině hodnotové priority usměrnují rozhodování, např́íklad o stanovení cílů organizace a formulování nových linií politiky (Rokeach podle Suchánková 1990: 533).

2. Analýza jakékoliv zahraniční politiky nemůže být redukována na výzkum jejích cílů a nástrojů. Efektivní zahraniční politika spočívá na sdíleném významu národní identity, postavení státu ve světě, jeho spojencích a neprátelích a jeho zájmech a aspiracích (Hill a Wallace 1996: 8). Otázka po zahraniční politice státu je vždy otázkou po jeho identitě. Samotnou identitu formuluje politická reprezentace na základě skutečností, k nimž se daná společnost hlásí a v nichž se poznává (Drulák 2009). Analýza zahraniční politiky tak musí mj. zahrnovat analýzu společnosti a zahraničně-politických elit, stejně jako společenských zájmů, aspirací a hodnot.

Otázka hodnotových preferencí, idejí a identity společnosti a tvůrců zahraniční politiky je $\mathrm{v}$ českých podmínkách mimořádně důležitá zejména proto, že revoluce roku 1989 vynesla na místo politické elity skupinu, která do té doby stála na okraji společnosti (rozuměj př́slušníky disentu) a sdílela očividně jinou kulturu a civilizační kompetence (srovnej Sztompka 1996) než zbytek společnosti. Výsledky revoluce 1989 a „návrat do Evropy“ vedly k zavržení staré (blokové) kultury a $\mathrm{k}$ výstavbě nového společenského řádu vycházejícího 
ze směsice národní a západní kultury globalizace (pro vymezení jednotlivých kultur srovnej Sztompka 1990). Tezí, kterou chci v následujícím textu ověrit, je, že po roce 1989 v souvislosti s „návratem do Evropy“ a přijetím západní kultury dochází v české společnosti k posunu od materialismu k postmaterialismu, podobně jako tomu bylo v západoevropských společnostech v 70. letech 20. století, prričemž u tvưrců zahraniční politiky je posun markantnější než u celku společnosti. Došlo-li v české společnosti a u české zahraničně-politické elity k transformaci hodnotových preferencí, lze očekávat i změnu činnosti, postojů, prezentace sebe sama ve vztahu k druhým, hodnocení, posuzování a ospravedlňování.

Pokud bych potvrdila změnu hodnotových preferencí směrem k postmaterialismu jak u české společnosti, tak u tvůrců zahraniční politiky, otevřela bych prostor pro další výzkum: na základě metody analogie bychom mohli předpokládat, že zvyšující se míra postmaterialismu povede $\mathrm{v}$ českém př́padě - podobně jako $\mathrm{v}$ př́padech západoevropských (srovnej Waisová a Cabada 2009) - $\mathrm{k}$ oslabení pragmatického př́stupu $\mathrm{k}$ zahraniční politice a oslabení relativizace hodnotového rozměru zahraničně politické problematiky, $\mathrm{k}$ odmítnutí politiky selektivního zájmu a dvojího standardu a př́íklonu k principiální zahraniční politice.

V první části textu nejprve představím (učiním tak velmi stručně, nebot' tomuto tématu se věnovali v předchozích obdobích v českém prostředí již jiní autoři - například Rabušic 2000) koncepci Inglehartovy „tiché revoluce“, v níž se moderní společnosti mění na společnosti postmoderní. Ve druhé části textu budu analyzovat, zda revoluce roku 1989 a „návrat do Evropy“ otevřely dveře pro tichou revoluci v české společnosti, byt' s fázovým posunem dvaceti let. Ve třetí části si pak kladu otázku, zda se tichá revoluce projevila mezi tvůrci české zahraniční politiky. V závěru se pak zamýšlím nad tím, jaké dopady by mohla mít změna hodnotových preferencí české společnosti na zahraniční politiku České republiky.

\section{Tichá revoluce a přechod od materialismu k postmaterialismu}

V desetiletích následujících po druhé světové válce dochází v západních společnostech k mezigeneračnímu posunu od materialistických $\mathrm{k}$ postmaterialistickým hodnotám; tento posun označil autor zmíněného dualistického pojetí hodnot - Ronald Inglehart - za „tichou revoluci“, v níž se moderní společnosti mění na společnosti postmoderní. ${ }^{2}$

Základní Inglehartovou (1997) tezí je, že po druhé světové válce vkročily západní společnosti do nové éry své socioekonomické existence - do postindustriální vývojové fáze, která s sebou přinesla i změnu hodnotových priorit. Inglehart tuto změnu konceptualizoval jako posun od hodnot materialistických k postmaterialistickým. Pod materialistickými hodnotami rozumí zejména orientaci lidí na ekonomickou prosperitu, hmotné bezpečí, stabilní ekonomický růst a dodržování sociálního pořádku. Postmaterialistické hodnoty vidí $\mathrm{v}$ orientaci na svobodnou seberealizaci jedince, v důrazu občanů na možnost více se podílet

2 K závěru o zásadní hodnotové proměně západoevropských společností dospěli v průběhu 70. a 80. let i další badatelé zabývající se problematikou hodnotových priorit v postindustriálních společnostech. Ačkoliv existuje početná řada Inglehartových kritiků a Inglehart některé slabiny své koncepce „tiché revoluce“ sám přiznává, jeho teze nebyly zatím (komplexně) vyvráceny (pro přehledový text srovnej např́íklad Rabušic 1990 a 2000: 15 a nn). 
na důležitých vládních rozhodnutích, více ovlivňovat správu věcí veřejných v bezprostředním okolí, žít v kvalitním životním prostředí a ve snaze změnit neosobní aspekt života společnosti a vytvářet humánnější společnost, v níž myšlenky budou důležitější než peníze (Inglehart podle Rabušic 1990: 506). Podle Ingleharta (1997) společnosti, které přijaly postmaterialistické hodnoty, mají větší sklon k důvěre a toleranci. Postmaterialisté nejsou ani anti-materialisté ani nematerialisté. „,Post-materialismus ‘ vyjadřuje sadu cílů, kterých má být dosaženo až poté, co lidé dosáhli materiální bezpečnosti, a jejich přijetí je umožněno, protože lidé dosáhli materiální bezpečnosti“ (Inglehart 1997: 35, kurzíva v originále).

Přechod $\mathrm{k}$ postmaterialismu se projevuje $\mathrm{i} \mathrm{v}$ institucionální rovině a politické sfére. Zatímco moderní společnost se vyznačovala hierarchickým a byrokratickým uspořádáním, postmoderní společnosti opouštějí byrokratický stát, disciplinované oligarchické politické strany, masovou produkci a tradiční odborové organizace (Inglehart 1997: 12-28). V politické oblasti přechod k postmaterialistickým hodnotám oslabil respekt vůči autoritám a loajalitu vůči hierarchickým politickým stranám a zvýšil zájem o politickou účast a sebevyjádření. Postmaterialistické aspirace spojené s očekáváním svobody generují potenciál k demokratickým reformám, a to prostřednictvím zvyšujícího se důrazu jedinců na demokracii a demokratický proces. Postmoderní společnosti už nechtějí jen volit, chtějí politické instituce a rozhodovací proces ovlivňovat daleko aktivněji (Inglehart 1997: 43).

Př́íčiny mezigeneračního posunu od materialistických k postmaterialistickým hodnotám spočívají v celé řadě socioekonomických změn, zejména v rozvoji demokratického politického systému a demokratických politických institucí, v bezprecedentním materiálním zabezpečení, které západní státy zažívají díky prosperitě nastolené v letech 1950-1970, a ve skutečnosti, že západní společnosti od druhé světové války žijí fakticky v míru. „Postmoderní společnosti už nemusejí bojovat o holé přežití, usilují spíše o maximalizaci subjektivního blahobytu“ (Inglehart 1997: 14 a 35). Postmoderní společnosti se vzdalují od standardizovaného funkcionalismu a nadšení pro vědu a ekonomický růst a berou daleko větší ohled na estetický a lidský prvek a na kvalitu života, život jako takový, jeho význam a hodnotu. Jinými slovy řečeno, dochází k nové percepci života a mění se životní postoje: Postmaterialisté kladou stále menší důraz na materiální spotřebu a ekonomickou jistotu a dávají naopak přednost cílům obecně lidským. Posun od materialistických k postmaterialistickým hodnotám se projevuje jak na individuální úrovni, tak na supraindividuální rovině. $\mathrm{V}$ př́padě politických elit např́klad při rozhodování o cílech státu či při formulování politik.

Podle sociologických výzkumů, které se zaměřují mj. na výzkum hodnotových preferencí (např́iklad European Values Study nebo World Values Survey), patří mezi společnosti s nejvyšší mírou postmaterialistické orientace, respektive s nejnižší mírou materialistické orientace společnosti států západní Evropy, především Dánska, Německa, Nizozemí, Norska, Švédska a Švýcarska (řazeno abecedně). ${ }^{3}$ Právě tyto státy v posledních třiceti letech významně reformovaly své zahraniční politiky, které dnes vykazují největší odklon od pragmatismu $\mathrm{v}$ zahraničně politických záležitostech a príklon $\mathrm{k}$ principiální zahraniční politice, jež je vzdálena politice selektivního zájmu a dvojího standardu (pro analýzu povahy německé, nizozemské a norské zahraniční politiky srovnej například Waisová a Cabada 2009).

3 World Values Survey: http://www.worldvaluessurvey.org/index_findings (navštíveno 20. 7. 2010). 


\section{Je česká společnost postmaterialistická? ${ }^{4}$ Tichá revoluce v Česku}

Česká společnost se po pádu komunismu přihlásila k evropskému Západu a Češi se vrátili k západnímu konceptuálnímu i hodnotovému pojetí vlastní identity. Odmítnutí „,barbarského“ Východu a přiznání se k identitě „civilizovaného“ Západu bylo vyjádřeno v českém „návratu do Evropy“, k návratu do rodiny civilizovaných liberálních demokratických společností. Návrat do Evropy vychází z Habermasovy myšlenky o „,nachholende Revolution“, kdy součástí návratu bylo „dohánění“, které mělo posouvat českou společnost po „stejné“ vývojové trajektorii, po které prošly po druhé světové válce západoevropské společnosti. To by postupně vedlo k tomu, že česká společnost získá podobné charakteristiky jako společnosti, mezi které patří (rozuměj západoevropské), a z jejichž skupiny byla jen dočasně vyloučena.

Byt' je zřejmé, že vývojová trajektorie české společnosti nemůže plně kopírovat vývoj v západoevropských společnostech, a to kvůli odlišným vnějším okolnostem - historické zkušenosti Čechů a charakteru české společnosti -, některé procesy, které se odehrávaly v západních společnostech v 70. letech, se v české společnosti logicky objevily v souvislosti $\mathrm{s}$ přechodem $\mathrm{k}$ demokracii po roce 1990. Jedná se mj. o mezigenerační posun $\mathrm{v}$ hodnotových preferencích jednotlivců a společnosti či o kvantitativní proměny v rodinném, tj. sňatkovém a reprodukčním chování populace, respektive o návrat k evropským vzorcům reprodukčního a rodinného chování (Možný a Rabušic 1998: 92).

Otázku, zda ,je česká společnost postmaterialistická“, si před deseti lety a deset let po zahájení přechodu České republiky k demokracii, položil sociolog - znalec Inglehartova díla - Ladislav Rabušic. Rabušic (2000: 13) konstatuje, že na základě sociologických výzkumů zjištujujíćch údaje o postmaterialismu v české populaci lze hovořit o „náznaku trendu $\mathrm{k}$ určité postmaterializaci, byt' procentuální rozdíly v počtech postmaterialistů mezi lety 1991 a 1999 nejsou velké a pohybují se na hranici výběrové chyby“. Vývoj do roku 2008 tento závěr potvrdil, nebot' podíl postmaterialistů se mezi léty 1991 a 2008 zdvojnásobil (srovnej tabulku 1).

Tabulka 1: Podíl materialistů a postmaterialistů v ČR v letech 1991, 1993, 1999 a 2008 (v \%)

\begin{tabular}{|l|c|c|c|}
\hline Typ/rok & 1991 & 1999 & 2008 \\
\hline Materialisté & 31 & 24 & 25 \\
\hline Smíšení & 64 & 67 & 65 \\
\hline Postmaterialisté & 5 & 9 & 10 \\
\hline
\end{tabular}

Zdroj: European Values Study 2008 (blǐže o tomto datovém zdroji viz editorial tohoto čísla), data byla získána prostřednictvím Inglehartovy čtyřpoložkové baterie.

Rabušic (2000: 14) připomíná, že důležitým třídicím kritériem posunu v hodnotové orientaci společnosti je věk. Pokud při výzkumu postmaterialismu české společnosti zohledníme právě věk, pak existují významné kohortní rozdíly, kdy v mladších kohortách (18-29 let) je růst podílu postmaterialistů zřetelný. Tyto mladší věkové kohorty vyrůstaly $\mathrm{v}$ období

4 Tuto otázku použil v roce 2000 L. Rabušic jako nadpis svého článku zkoumajícího proměnu hodnotových preferencí české společnosti. 
relativního blahobytu konce 70 . a první poloviny 80 . let, současně však sekundární a terciární vzdělání a první pracovní zkušenosti získávaly už po roce 1989. Rozdíl v podílech postmaterialistů mezi nejmladší generací v roce 1991 a 1999 je již mimo rámec výběrové chyby, a je tedy možno konstatovat (přijmeme-li Inglehartův způsob měření a tvorbu jeho typologie jako validní), že „V průběhu 90. let dochází ve vývoji české společnosti k posunu hodnotových preferencí způsobem, který lze označit za trend snížení materialistických postojů a k jistému př́klonu k postojům postmaterialistickým“ (Rabušic 2000: 15). Rabušic došel v roce 2000 k závěru, že postmaterialistická dimenze je v české populaci př́itomna, má tendenci k nárůstu a jejími nositeli jsou především nejmladší členové české dospělé populace (Rabušic 2000: 19). Výsledky EVS ze třetí české vlny výzkumu EVS z roku 2008 tento trend, jak ukazuje tabulka 2, potvrzují. Podíly postmaterialistů se v nejmladší věkové skupině od roku 1991 do roku 2008 zdvojnásobily (a zvyšovaly se i v dalších věkových skupinách), naopak podíly materialistů se v každé věkové skupině snížily.

Tabulka 2: Rozložení materialistů a postmaterialistů v české populaci podle věkových skupin ( $\%$ \%) v letech 1991, 1999 a 2008

\begin{tabular}{|l|c|c|c|c|c|c|}
\hline & \multicolumn{3}{|c|}{ Materialisté } & \multicolumn{3}{c|}{ Postmaterialisté } \\
\hline Věk & 1991 & 1999 & 2008 & 1991 & 1999 & 2008 \\
\hline 18-29 let & 19 & 21 & 13 & 7 & 13 & 14 \\
\hline 30-44 let & 27 & 23 & 23 & 7 & 10 & 10 \\
\hline 45-59 let & 35 & 23 & 28 & 5 & 8 & 10 \\
\hline 60 let a starší & 42 & 31 & 37 & 2 & 8 & 6 \\
\hline
\end{tabular}

Zdroj: EVS 2008.

Poznámka: $\vee$ tabulce nejsou uvedeny podíly łzv. smíšených.

Byt’ předložená čísla podpořila moji tezi o nárůstu postmaterialismu v české společnosti, není nárůst počtu postmaterialistů v celkových číslech zcela přesvědčivý. Proto se pokusím tezi o transformaci hodnotových priorit české společnosti a fakt, že tato transformace probíhá po podobné trajektorii, po jaké probíhala v západních společnostech v 70. a 80 . letech, podpořit i dalšími argumenty.

Jako ověřovací nástroj můžeme použít výzkum demografického chování, nebot' právě významná změna demografického chování odrážející se ve změnách vzorců porodnosti, sňatkovosti a úmrtnosti - která byla označena za druhou demografickou tranzici - provázela v západních společnostech na přelomu 60. a 70. let mezigenerační posun od materialismu k postmaterialismu. Hospodářský vzestup západních společností spojený s rozvojem demokracie a sociálního státu, nárůstem vzdělanosti a masivním nástupem žen do placeného zaměstnání poznamenaly životní filozofii a hodnotové orientace nově nastupujících generací a na počátku 70. let proměnily sociální a reprodukční klima západoevropských společností (Možný a Rabušic 1998: 106).

Demografické statistiky prozrazují, že změny ve vzorcích porodnosti, sňatcích a úmrtnosti, ke kterým došlo v České republice po roce 1989, jsou podobné a stejně hluboké, jako změny, které se objevily v západních společnostech v 70. a 80. letech. V České republice dochází od poloviny 90 . let k tzv. druhé demografické tranzici a jejími příčinami jsou - jako 
na Západě - hluboké změny hodnotových priorit a preferencí nejmladších věkových kohort, kohort narozených od poloviny 70. let do počátku 80. let (Rabušic 2001, Možný a Rabušic 1998). Nová hodnotová orientace těchto kohort byla latentně př́itomná již před politickými změnami v roce 1989, avšak měla možnost se plně projevit až ve svobodném prostředí nové demokratické společnosti. Byt' se nyní zřejmě dopouštím sociologicky odvážného tvrzení, domnívám se, že změnu hodnotových priorit projevující se „návratem české rodiny do Evropy“ můžeme obecněji doložit závěry uvedenými výše - tedy že česká společnost, respektive její část, prochází podobnou strukturální změnou jako západní společnosti v 70 . a 80. letech, a lze tak očekávat, že v české společnosti bude posilovat míra postmaterialismu, podobně jako k tomu docházelo v západní Evropě. Zatímco v oblasti natality, sňatečnosti a mortality se změny projevují relativně brzy a jsou dobře měřitelné, v politické sféře dochází ke změně daleko pomaleji a vliv proměny hodnotových preferencí Čechů na tuto oblast je měřitelný obtížně.

Určitým dalším indikátorem hodnotových změn mohou být postoje Čechů k některým otázkám z politické oblasti: postoj $\mathrm{k}$ demokracii, respektive $\mathrm{k}$ charakteru politických systémů a režimů a některým konkrétním hodnotám (mír, lidská práva, spravedlnost, svoboda apod.). Přesto, že se velká část Čechů domnívá, jak říkají data z EVS 2008, že v demokracii funguje ekonomický systém špatně $(38 \%)$, že demokracie jsou nerozhodné a př́liš hašteřivé (52\%) a že v demokracii se těžko udržuje pořádek $(54 \%),{ }^{5}$ myslí si $83 \%$ Čechů, že demokracie je přes své problémy lepší než jiná forma vlády (EVS 2008). ${ }^{6}$ Lze registrovat i oblibu a aktivní účast ve veřejné podpoře demokratických hodnot a lidských práv. V české společnosti, zejména mezi mladými městskými intelektuály, získaly velkou podporu a oblibu akce na podporu lidských práv a obhájců lidských práv reprezentované v českém prostředí například účastí na mezinárodní kampani „Vlajka pro Tibet“. Nutno však dodat, že podpora některých lidsko-právních témat (Tibet) se u určitých skupin české společnosti stává spíše výrazem politického kýče ${ }^{7}$ než reprezentací jejich vnitřních hodnot ústících v obhajobu lidských práv. Př́íkladem budiž dodatek k jídelnímu lístku Petit Cafe v Mikulově: „Všichni Tibet’ané u nás mají vše zdarma, aby se cítili aspoň někde jako doma.“ Proč nemají vše zdarma například i Ujguři, Kurdové či Karenové?

O charakteru české společnosti a jejích hodnotových preferencí vypovídá také srovnání postojů Čechů k některým otázkám s postoji obyvatel dalších evropských zemí. Mezi třemi hodnotami ${ }^{8}$ které Češi v roce 2008 uváděli v šetření Eurobarometru jako pro ně osobně nejdůležitější, byly respekt vůči lidským právům, mír a respekt k lidskému životu. Všechny

5 Pro srovnání, podle šetření EVS 1999 byla čísla vztahující se ke zmíněným otázkám následující: $35 \%$ Čechů souhlasilo, že v demokracii funguje ekonomický systém špatně, 51 \% Čechů souhlasilo, že demokracie jsou nerozhodné a př́liš hašteřivé, a $54 \%$ pak s tím, že v demokracii se těžko udržuje pořádek (EVS 2008).

6 V EVS 1999 zastávalo myšlenku, že demokracie je i přes své problémy lepší než jiná forma vlády, $92 \%$ Čechů, v roce 2008 se stejnou myšlenkou souhlasilo $83 \%$ obyvatel ČR (EVS 2008).

7 Pro otázku postojů české společnosti k Tibetu srovnej např́íklad (Fürst 2010).

8 Respondenti si museli vybrat z následující sady hodnot: lidská práva, mír, demokracie, právní řád, úcta k jiným kulturám, solidarita a podpora druhých, úcta k lidskému životu, rovnost, individuální svoboda, tolerance, sebenaplnění a víra a náboženství (Eurobarometer 69: 22). 
tyto hodnoty si vybralo ze sady celkem dvanácti dalších hodnot téměř $40 \%$ obyvatel, konkrétně respekt vůči lidským právům za svou nejdůležitější hodnotu zvolilo $40 \%$ Čechů stejně jako mír, 38\% Čechů za svou třetí nejdůležitější hodnotu zvolilo respekt k lidskému životu (Eurobarometer 69: technické specifikace, nestránkovaná př́lloha). Pokud výsledky českého šetření srovnáme s EU 27, pak se v Evropské unii počet těch, kteří si vybrali zmíněné hodnoty, pohyboval také kolem $40 \%$ (45\% pro mír, $42 \%$ pro respekt $\mathrm{k}$ lidským právům a $41 \%$ pro respekt $\mathrm{k}$ lidskému životu), přičemž v této věci nelze vysledovat žádný zásadní rozdíl mezi hodnotovými preferencemi českých občanů a občanů starých členských zemí EU (tedy západoevropských zemí, v nichž v 70. letech proběhla tichá revoluce) (Eurobarometer 69: 15-16). V dalších srovnávacích výzkumech hodnot a hodnotových preferencí občanů členských zemí EU pak Češi vykazují vyšší míru tolerance ke kriminalitě a akceptují mírnější postihy kriminality, než je tomu v průměru v členských zemích EU 25 (výzkumy jsou z roku 2006), což souvisí i s tím, že česká veřejnost klade nadprůměrný důraz na osobní svobodu (Eurobarometer 66: 7). Obecně lze rríci, že v otázkách testujících míru liberalismu společnosti česká společnost bud' převyšuje úroveň EU 25 (tj. je výrazně liberálnějšíi) ${ }^{10}$, nebo se pohybuje přibližně na průměru EU 25 , přičemž v otázkách hodnotových preferencí se spíše blíží státům původní EU 15 a vzdaluje novým členským zemím (Eurobarometer 66).

I na základě výše uvedených údajů lze potvrdit Rabušicův závěr z roku 2000, že „ve vývoji české společnosti dochází k posunu hodnotových preferencí způsobem, který lze označit za trend snížení materialistických postojů, a k jistému př́klonu k postojům postmaterialistickým“" (Rabušic 2000). Nejvýraznější je tento posun u nejmladších věkových skupin.

\section{Postmaterialismus mezi tvưrci zahraniční politiky}

Pokud se vrátíme k tezi o zdrojích transformace povahy české zahraniční politiky a k argumentu, že jedním z těchto zdrojů je změna hodnotových preferencí, idejí/ideologie a vnímání identity (české) společnosti u tvůrců zahraniční politiky, pak je třeba vedle hodnotových priorit české společnosti a jejich změny zkoumat také hodnotové priority těchto jedinců. Za tvůrce zahraniční politiky považuji skupinu lidí, kteří jsou zapojeni do zahraničně-politických záležitostí. Tvůrce zahraniční politiky lze rozdělit na formální a neformální. Za formální tvưrce zahraniční politiky považuji osoby, z jejichž popisu práce vyplývá, že se podílejí na tvorbě či výkonu české zahraniční politiky. Mezi tyto osoby řadím prezidenta, členy vlády, nejvyšší ministerské úředníky, členy parlamentu a nejvyšší př̌edstavitele samosprávných celků. Za neformální tvůrce zahraniční politiky považuji ty osoby a skupiny, které nezastávají mocenské pozice, ale ovlivňují zahraničně-politické záležitosti: politické

9 Jen namátkou, mezi starými členskými státy EU si mír a respekt k lidským právům a lidskému životu jako své nejdůležitější hodnoty vybrali Belgičané, Němci, Francouzi, Nizozemci či Švédové. Mír si jako svou nejdůležitější hodnotu mezi obyvateli EU zvolili Němci (62\% obyvatel), respekt k lidským právům Kypřané a Švédové (63\%) a respekt k lidskému životu Irové (53\%) (Eurobarometer 69: 16).

10 Povolení sňatků homosexuálů či legalizace konzumace marihuany pro osobní potřebu, tolerance kriminality byla již zmíněna (Eurobarometer 66: 41). 
strany, nevládní organizace, firmy, média, univerzity, poradce a poradní skupiny a odbory. Analyzovat hodnotové preference formálních a neformálních tvůrců zahraniční politiky je velmi obtížné, nebot' v současnosti nemáme k dispozici žádný soubor sociologických dat vztahující se k této skupině. Existují výzkumy českých politických a ekonomických elit (Machonin, Tuček a další), nicméně ty nezohledňují podskupiny, jakými jsou zahraničně-politické elity, či neformální tvůrce zahraniční politiky. Usuzovat o hodnotových preferencích formálních a neformálních tvůrců české zahraniční politiky a počtu postmaterialistů $\mathrm{v}$ této skupině tak lze jen zprostředkovaně.

Vyjdu z poznatku sociologů (Machonin a Tuček 2002: 13; Hanley, Matějů, Vlachová a Krejčí 1998: 7-9 a 25), že:

1. Př́slušníci nových českých politických elit se rekrutovali z dětí inteligence, tedy ze skupiny, jejíž př́ijmová úroveň nebyla před rokem 1990 o nic vyšší než př́ijmová úroveň ostatního obyvatelstva, ale jejíž vzdělání, kulturní úroveň a charakter práce byly podstatně vyšší.

2. Tř́iní status byl v socialistických společnostech nahrazen vlastnictvím znalostního kapitálu spojeného se vzděláním. Toto naznačuje - a dokládají to i sociologické průzkumy (např. Hanley, Matějů, Vlachová a Krejčí 1998: 34) -, že členové politických elit mají vysoké vzdělání. V roce 1998 nemělo terciární vzdělání $25 \%$ zaměstnancủ státní správy a $19 \%$ členů parlamentu. Samotná zahraničně-politická služba má taková specifika (např́íklad vysoké nároky na znalost jazyků či komunikační schopnosti, nároky na všeobecný přehled), která terciární vzdělání jednoznačně předpokládají, což je potvrzeno např́ílad i tím, že jednou z podmínek k přijetí na diplomatickou akademii MZV ČR je ukončené vysokoškolské vzdělání minimálně magisterského, respektive inženýrského stupně. ${ }^{11}$

S ohledem na výše uvedené lze předpokládat, že mezi tvưrci zahraniční politiky je počet lidí s terciárním vzděláním ještě vyšší než u skupiny označované jako politické, respektive mocenské elity. Vysokoškolské vzdělání měli všichni ministři zahraničních věcí České republiky, všichni jejich náměstci a většina členů zahraničního výboru Poslanecké sněmovny Parlamentu ČR a Výboru pro zahraniční věci, obranu a bezpečnost Senátu ČR. Celkově v letech 1992-2010 působilo v zahraničním výboru PSP ČR 109 poslanců, z nichž šest nemělo vysokoškolské vzdělání (jeden z těchto šesti VŠ nedokončil úspěšně a nyní je znovu zapsán ke studiu). Procentuálně vyjádřeno, v letech 1992-2010 nemělo vysokoškolské vzdělání $6,5 \%$ poslanců účastnících se práce zahraničního výboru PSP ČR. V jednotlivých volebních obdobích rozložení vysokoškoláků a ostatních vypadalo takto: 1992-1996 17 poslanců s VŠ, 1 bez VŠ; 1996-1998 23 poslanců s VŠ, 2 bez VŠ; 1998-2000 18 poslanců s VŠ, 2 bez VŠ; 2002-2006 všichni poslanci výboru měli VŠ; 2006-2010 19 poslanců s VŠ, 1 VŠ studuje. V prípadě Senátu ČR za období 1996-2010 (zde neuvádíme počty po obdobích, nebot' Senát se obměňuje každé dva roky vždy z jedné třetiny) působilo ve Výboru po zahraniční věci, obranu a bezpečnost 40 senátorů, z nichž 9 nemělo vysokoškolské vzdělání. Mezi těmito devíti pak byl jeden, který VŠ nedokončil. Pokud bychom vyjádřili uvedené číslo v procentech, pak v letech 1996-2010 nemělo vysokoškolské vzdělání 22,5\% členů

11 Výběrové řízení ke studiu na Diplomatické akademii MZV ČR: http://www.mzv.cz/jnp/cz/o_ministerstvu/diplomaticka_akademie/vyberove_rizeni_ke_studiu_na.html (Navštíveno: 15. 4. 2010). 
Výboru pro zahraniční záležitosti, obranu a bezpečnost Senátu ČR..$^{12}$ Byt' je počet vysokoškoláků v obou komorách Parlamentu ve výborech zabývajících se zahraniční politikou vysoký, v Senátu je zřetelně nižší než v Poslanecké sněmovně. Tuto skutečnost lze vysvětlit způsobem volby do Senátu, kde pravidlo volitelnosti mj. obsahuje podmínku čtyřiceti let věku. V Senátu, kde jsou významně zastoupeni disidenti (do roku 2006 včetně kolem $20 \%$ - srovnej Waisová a Piknerová 2010), se vyskytuje relativně velký počet lidí, kteří nemohli před rokem 1989 studovat.

Př́ímou odpověd' na otázku, zda jsou české zahraničně politické elity postmaterialistické, nemáme, ale domnívám se, že ji lze získat zprostředkovaně, a to právě za použití předpokladu vyšší vzdělanostní úrovně této skupiny. Pokud je tvrzení o vzdělanostní úrovni zahraničně-politických elit správné, pak můžeme použít odpovědi respondentů získané v EVS, kteří se vyjádřili $\mathrm{k}$ baterii otázek testujících míru postmaterialismu (celkem je to 5823 respondentů) a jako tř́́dicí kritérium pro tuto skupinu použít vzdělání. Následující tabulky jasně demonstrují, že počet postmaterialistů koreluje s úrovní vzdělání, respektive že mezi lidmi s vysokoškolským vzděláním se vyskytuje nižší počet materialistů a vyšší počet smíšených postojů a postmaterialistů. Jak jsem demonstrovala výše, $v$ zahraničně-politické elitě je vysoký počet lidí s vysokoškolským vzděláním, proto lze dovodit, že mezi zahraničně-politickou elitou je také vyšší počet lidí, kteří nesmýšlejí materialisticky, ale řadí se do skupiny postmaterialistů či smíšených typů.

Takto učiněný závěr však není bez problémů. Jako problematická se jeví zejména otázka charakteru vysokoškolského vzdělání, tj. jaké vysokoškolské vzdělání měli/mají tvůrci zahraniční politiky a zda (ne)existuje korelace mezi vystudovaným oborem vysoké školy a postmaterialistickou orientací. Dalo by se předpokládat, že humanitně a sociálně vzdělaní lidé mají s ohledem na směřování jejich studia vyšší postmaterialistickou orientaci, a současně, že tato skupina ze stejného důvodu jeví o zahraniční politiku větší zájem. Pokud však nahlédneme do Parlamentu či na ministerstvo zahraničních věcí, ukazuje se, že lidé s humanitním vzděláním nepřevažují a nezaujímají ani jinak významné místo. Otázkou by také mohly být př́ijmové rozdíly mezi humanitně a technicky vzdělanými jedinci. Výzkumy průměrné mzdy v ČR a strukturální mzdové statistiky Českého statistického úřadu ukazují, že technicky vysokoškolsky vzdělaní odborníci mají vyšší mzdy než absolventi humanitních a sociálních věd. S nadsázkou by bylo možné spekulovat, že míra postmaterialistické orientace humanitně vzdělaných lidí by se neměla výrazně odlišovat od míry postmaterialismu lidí s technickým vysokoškolským vzděláním, byt' zdroj postmaterialistické orientace je odlišný. U jedněch je dána oborovou orientací, druzí mají vysoké mzdy a jsou materiálně uspokojeni (viz Inglehartova teze výše).

Námitkou proti tomuto postupu by mohlo být, že počet postmaterialistů by podle Inglehartovy logiky spíše koreloval s ekonomickým postavením respondentů než s úrovní vzdělání. Takovou námitku nelze odmítnout, nelze ji však ani potvrdit, nebot' nemáme dostatek údajů, kterými by se dala její platnost ověřit. V European Values Study se za léta 1991, 1999 a 2008 k baterii otázek testujících postmaterialismus vyjádřilo 5823 respondentů, 3882 z těchto respondentů však nebylo ochotno odpovědět na otázku o výši svých př́jmů. Počet

12 Za pomoc při hledání a tř́dění těchto dat děkuji kolegyni Lindě Piknerové. 
těch, kteří byli ochotni informovat o výši svých př́ijmů, byl tak malý, že jej nelze považovat za reprezentativní vzorek, z něhož bychom mohli usuzovat o platnosti korelace mezi výší př́jmů a postmaterialistickou orientací české společnosti.

Lze také namítat, že lidé s vyšším vzděláním jsou na trhu práce úspěšnější a zastávají lépe placená povolání a že lidé se vzděláním vykazují postmaterialistickou orientaci, protože se mají obecně lépe. Tuto námitku lze - minimálně v českém prŕípadě - také zpochybnit, nebot' zejména v letech 1968-1989 docházelo k výrazné společenské korupci, z níž profitovaly zejména méně kvalifikované vrstvy společnosti (srovnej např́klad Machonin 1996: 177), nikoliv vysokoškoláci. Na počátku 90 . let byly ekonomické rozdíly ve společnosti minimální, přesto je z výsledků EVS z roku 1991 (viz tabulka 3) zřejmé, že mezi vysokoškoláky (kteří se neměli ekonomicky lépe než zbytek společnosti) je počet materialistů nejnižší. Jinými slovy, i v době, kdy vysokoškoláci sdíleli průměrnou životní úroveň československých občanů, vykazovali nižší tendenci k materialistické orientaci.

Tabulka 3: Rozložení materialistů a postmaterialistů v české populaci v jednotlivých vzdělanostních skupinách v letech 1991, 1999 a 2008 (v \%)

\begin{tabular}{|c|c|c|c|c|}
\hline \multicolumn{5}{|c|}{1991} \\
\hline Vzdělání & Materialisté & Smíšení & Postmaterialisté & Celkem \\
\hline Základní & 43 & 55 & 3 & 100 \\
\hline Vyučen & 32 & 63 & 5 & 100 \\
\hline Střední & 25 & 68 & 7 & 100 \\
\hline Vysokoškolské & 19 & 72 & 9 & 100 \\
\hline \multicolumn{5}{|l|}{1999} \\
\hline Základní & 38 & 55 & 7 & 100 \\
\hline Vyučen & 27 & 68 & 5 & 100 \\
\hline Střední & 18 & 70 & 13 & 100 \\
\hline Vysokoškolské & 11 & 71 & 18 & 100 \\
\hline \multicolumn{5}{|l|}{2008} \\
\hline Základní & 37 & 57 & 6 & 100 \\
\hline Vyučen & 31 & 61 & 9 & 100 \\
\hline Střední & 26 & 64 & 11 & 100 \\
\hline Vysokoškolské & 13 & 74 & 14 & 100 \\
\hline
\end{tabular}

Zdroj: EVS 2008

\section{Závěrem}

Za dvacet let od pádu komunismu se česká společnost, její hodnoty, návyky a způsoby jednání výrazně změnily - česká společnost se „vrátila do Evropy“ a přiblížila se svými civilizačními kompetencemi západoevropským společnostem. Změna hodnotových preferencí, která u nás probíhá po roce 1989 , je podobná tzv. tiché revoluci, $\mathrm{k}$ níž došlo $\mathrm{v} 70$. letech v západoevropských společnostech, a vede k posílení postmaterialistické orientace české populace. Předložený text ukazuje, že česká společnost prochází tichou revolucí, i když ke změně hodnotových preferencí dochází relativně pomalu. Nejvýrazněji je změna hodnotových preferencí od materiálních hodnot $\mathrm{k}$ hodnotám postmateriálním vidět u nejmladších 
věkových kohort. Vedle nejmladších věkových kohort můžeme výraznější postmaterialistickou orientaci (včetně jejího nárůstu $\mathrm{v}$ čase) zaznamenat u lidí s vysokoškolským vzděláním. Při analýze české zahraniční politiky vycházíme z toho, že identitu státu formuluje politická reprezentace na základě skutečností (hodnot), $\mathrm{k}$ nimž se daná společnost hlásí a v nichž se poznává, a hodnoty řídí a determinují její jednání a postoje. Platí-li, že hodnotové preference české společnosti a zejména tvůrců zahraniční politiky procházejí změnou, lze očekávat, že tato změna vyvolá změnu další, $v$ tomto príípadě změnu povahy zahraniční politiky. Tomu nasvědčuje i fakt, že mezi tvůrci zahraniční politiky převažují lidé s vysokoškolským vzděláním, jejichž postmaterialistická orientace v posledních dvaceti letech kontinuálně roste a je současně výrazně vyšší než u celé populace a je i mírně vy̌̌ší než u nejmladší věkové kohorty jako takové.

Uvažujeme-li o změně povahy české zahraniční politiky, pak může mít postmaterialistická orientace české společnosti a tvůrců zahraniční politiky vliv zejména na cíle a postupy zahraniční politiky. Zahraniční politiky zemí, jejichž společnosti vykazují vysokou míru postmaterialismu, vykazují nižší míru pragmatismu, respektive vy̌̌ší míru principiality a odmítání politiky selektivního zájmu a dvojího standardu. Pokles materialistické orientace koreluje s vy̌šsím zájmem o obhajobu lidských práv včetně podpory rozvoje humanitárního práva a demokratizace, $\mathrm{s}$ ochotou strpět vyšší náklady na ochranu národní bezpečnosti za předpokladu použití zbraní s minimálním negativním humanitárním dopadem, s vyšším zájmem o osud těch, kteří žijí za našimi hranicemi, a s vyšším zájmem o ochranu životního prostředí. Státy, jejichž společnosti vykazují vysokou míru postmaterialismu, se stávají obhájci, propagátory a nositeli takových aktivit, jako jsou zákaz nášlapných min (Ottawská úmluva) a kazetové munice (Dohoda z Osla), zř́zení Mezinárodního trestního soudu a rozšírení členství či přijetí a prosazení principu Odpovědnosti za ochranu. Zda tímto směrem půjde česká zahraniční politika, uvidíme v následujících desetiletích. Stávající postup české zahraniční politiky zatím naznačuje (srovnej napríklad Waisová 2011), že úvaha o vlivu změny hodnotové orientace české populace a tvůrců zahraniční politiky na povahu české zahraniční politiky byla správná.

\section{Literatura}

DRULÁK, Petr. Proč nám nestačí splývat? Lidové noviny [online]. 3. října 2009. [cit. 2010-1012]. Dostupné na www: <http://www.lidovky.cz/proc-nam-nestaci-splyvat-0x3-/ln_noviny. asp?c=A091003_000100_ln_noviny_sko\&klic $=233571 \&$ mes $=091003 \_0>$.

Eurobarometer 66. Národní zpráva : Česká republika. Podzim 2006. Evropská komise.

Eurobarometer 69. Values of Europeans (Field work: March-May 2008, Publication : November 2008). European Commission.

European Values Study [online]. 2008. [cit. 2010-10-12]. Dostupné na www: <http://www.europeanvaluesstudy.eu/>.

FÜRST, Rudolf. Podpora Tiberu, Tchaj-wanu a lidských práv v Č́ně: Evropská avantgarda nebo český kýč? In DRULÁK, P., HORKÝ, O. (eds.) Hledání českých zájmů II. Obchod, lidská práva a mezinárodní rozvoj. Praha : Ústav mezinárodních vztahů, 2010, s. 80 - 101. ISBN 978-80-86506-87-6. 
HANLEY, Eric ; MATĚJŮ, Petr ; VLACHOVÁ, Klára ; KREJČÍ, Jindřich. The Making of Post-Communist Elites in Eastern Europe. 1998. [Working papers of the research project-Social Trends 4/1998]. ISBN 80-85950-54-5.

HILL, Christopher ; WALLACE, William. Introduction : Actors and Actions. In HILL, Ch. (ed.) The Actors in Europe's Foreign Policy. Londýn : Routledge, 1996, s. 1 - 16. ISBN 0-415-12222-8.

INGLEHART, Ronald. Modernization and Postmodernization. Cultural, Economic and Political Change in 42 Societies. New Jersey : Princeton University Press, 1997. 440 s. ISBN 0-691-01181-8.

MACHONIN, Pavel ; TUČEK, Milan. Zrod a dalši vývoj nových politických elit v České republice (od konce osmdesátých let 20. století do jara 2002). Praha : Sociologický ústav AV ČR, 2002. ISBN 80-7330-011-7.

MACHONIN, Pavel. Modernisation and Social Transformation in the Czech Republic. Czech Sociological Review, 1996, roč. 32, č. 2, s. 171 - 186. ISSN 1210-3861.

MOŽNÝ, Ivo ; RABUŠIC, Ladislav. Česká rodina, sňatkový trh a reprodukční klima. In VEČERNÍK, J. (ed.) Zpráva o vývoji české společnosti 1989-1998. Praha : Academia, 1998, s. 92 - 112. ISBN 80-2000-0703-2.

RABUŠIC, Ladislav. Tichá revoluce neboli od materialismu $\mathrm{k}$ postmaterialismu v západních společnostech. Sociologický časopis, 1990, roč. 26, č. 6, s. 505 - 517. ISSN 0038-0288.

RABUŠIC, Ladislav. Je česká společnost „,postmaterialistická“"? Sociologický časopis, 2000, roč. 36, č. 1, s. 3 - 22. ISSN 0038-0288.

RABUŠIC, Ladislav. Value Change and Demographic Behaviour in the Czech Republic. Czech Sociological Review, 2001, roč. 37, č. 1, s. 99 - 122, ISSN 1210-3861.

SUCHÁNKOVÁ, Marie. O problematice americké sociologie hodnot. Sociologický časopis, 1990, roč. 26, č. 6, s. $526-536$. ISSN 0038-0288.

SZTOMPKA, Piotr. Pohled zpět : Rok 1989 jako kulturní a civilizační zlom. Sociologický časopis, 1996, roč. 32, č. 1, s. 5 - 20. ISSN 0038-0288.

WAISOVÁ, Šárka ; CABADA, Ladislav. Etika a mezinárodní politika. Plzeň : Vydavatelství a nakladatelství Aleš Čeněk, 2009. 240 s. ISBN 978-80-7380-260-8.

WAISOVÁ, Śárka. Tíha volby. Česká zahranični politika mezi principy a zájmy. Praha : Ústav mezinárodních vztahů, 2011. [v tisku].

WAISOVÁ, Šárka ; PIKNEROVÁ, Linda. Twenty Years After : Dissident Tradition in Czech Foreign Policy Matters. 2010. [v tisku].

\section{Autorka}

působí na katedře politogie a mezinárodních vztahů FF ZČU a v roce 2010 působila jako výzkumná pracovnice Ústavu mezinárodních vztahů v Praze. Je autorkou několika monografií a odborných článků zabývajících se analýzou zahraniční politiky, řešením konfliktů a mezinárodní bezpečností.

Kontakt:waisova@kap.zcu.cz 